DEPARTMENT OF THE INTERIOR
UNITED STATES GEOLOGICAL SURVEY

PREPARED IN COOPERATION WITH

THE COMMONWEALTH OF KENTUCKY, UNIVERSITY OF KENTUCKY

KENTUCKY GEOLOGICAL SURVEY

WALLACE W. HAGAN, DIRECTOR AND STATE GEOLOGIST

\title{
MAP SHOWING BEDROCK TOPOGRAPHY AND SUBCROP OF A SELECTED BED BENEATH ALLUVIAL DEPOSITS OF PART OF THE WILSON QUADRANGLE, HENDERSON COUNTY, KENTUCKY By \\ Avery E. Smith and Thomas E. Ball
}

\begin{abstract}
MISCELLANEOUS GEOLOGIC INVESTIGATIONS
MAP I-859
\end{abstract}

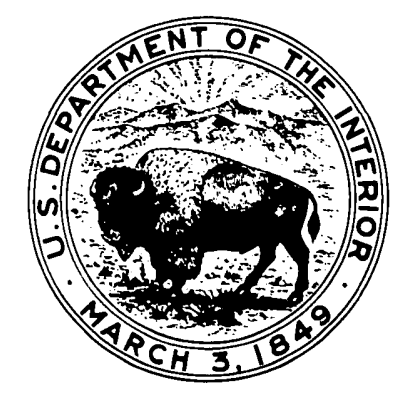

PUBLISHED BY THE U.S. GEOLOGICAL SURVEY

WASHINGTON, D.C. 20244

1974 